\title{
DIGNITY IN THE CONTEXT OF ORGANIZATIONS: A LOOK BEYOND MODERNITY
}

\section{MICHEL MOTT MACHADO}

$\mathrm{PhD}$ in Business Administration from the Department of Business Administration, Universidade Presbiteriana Mackenzie (UPM).

Associate Professor at the Department of Business Administration, Universidade de Mogi das Cruzes (UMC).

Av. Dr. Cândido Xavier de Almeida e Souza, 200, Centro Cívico, Mogi das Cruzes - MG Brasil - CEP 08780-911

E-mail: michel.machado@umc.br

\section{MARIA LUISA MENDES TEIXEIRA}

$\mathrm{PhD}$ in Business Administration from the Department of Business Administration, University of São Paulo (USP).

Full Professor at the Graduate Program in Business Administration, Universidade Presbiteriana Mackenzie (UPM).

Rua da Consolação, 930, Consolação, São Paulo - SP - Brasil - CEP 01302-907

E-mail: malluluisa@gmail.com 


\section{ABSTRACT}

Purpose: This article aims to reflect, from the perspective of critical post modernity, on a possible conceptual proposition about dignity in organizations.

Originality/gap/relevance/implications: In the field of organizational studies, dignity in organizations has not been considered through the perception of a world of intense movement of capital, technology, goods, workers, and employees between organizations, as well as the migration between countries of citizens of different countries. It is argued, therefore, that the design of such phenomenon should examine in depth the respect for different knowledges, besides the idea of interculturalism.

Key methodological aspects: As there are few papers written about this theme, our paper is a theoretical essay.

Summary of key results: Taking the concept of dignity as a starting point, we tried first to outline a conceptual approach aimed at transposing its sociopolitical perspective, and then to propose a perspective on dignity in organizations that transcends modernity. Ideas on the ecology of knowledges, relationships of shared authority, and respect for the principles of equality and difference, beyond reciprocal recognition and the availability for mutual enrichment, were the qualifying elements in defining our conceptual propositions.

Key considerations/conclusions: As a theoretical contribution, we sought to introduce a new perspective on the dignity phenomenon; thus, we tried to break through, in this field of studies, with a view that understands dignity and emancipation as a single concept, in which the new element would be interculturalism.

\section{KEYWORDS}

Dignity in organizations. Emancipation. Interculturalism. Modernity. Post modernity. 


\section{INTRODUCTION}

The concept of dignity found in dictionaries "is the result of a historical evolution, arising from existing views on the subject in different periods" (Araújo, 2011, p. 21). Concerning this, companies have sought to identify the distinctive essential characteristics of the human being, and, in this way, dignity has taken different directions in different areas of knowledge, including common sense (Baker, 1961; Jacobson, 2007).

In the administration field, research has been conducted mainly on the perspective of dignity in organizations, especially the type connected to dignity at work. For Hodson (2001), moreover, the question of work could be regarded as essential dignity. In this sense, some studies have been conducted with a focus on dignity at work as a matter of law (Beitner, 1984; Brodie, 2004). Other scholars have tried to understand the relationship between the formal structure of the job and dignity, and related topics have been studied, such as processes of shutdown and downsizing (Barbee, 2001; Bayer, 2000; Greenspan, 2002), work design and dignity (Buchanan, 2001), positive and meaningful experiences related to participatory work organizations (Hodson, 1996), job security and wages for a decent life (Rayman \& Reynolds, 2001), finding a meaning for one's job (Hodson \& Roscigno, 2004), relationships between managers and employees (Sayer, 2007), and gender and dignity at work (Crowley, 2013).

In a sequence of research directed to market demands, competition, productivity, and dignity, there are studies that focus on respect for the dignity of the employee and on loyalty and productivity (Shahinpoor \& Matt, 2006); the balance between respect for human rights and performance, for a humanized, competitive, and successful organization (Morkhiber, 2001); and the matter of dignity, competitiveness, and performance (Auerbach, 1988).

Regarding dignity at work, there are studies focusing on the relationship between dignity and the content of the work itself, taking into consideration different professional fields, such as nursing (Chiappetta-Swanson, 2005; Lawless \& Moss, 2007), street sweepers and waste collectors (Santos \& Silva, 2009), and family caregivers (Stacey, 2005). Another front of this matter concerns the lack of respect for dignity at work. In this line of thought, studies can be found that mention bullying and harassment (Heloani, 2004; McMullen, 2011; Sayer, 2007), as well as exploitation of child labor, as a lack of respect for dignity (Campos \& Alverga, 2001).

More recently, a view has been developed based on stakeholders within the field (Teixeira, 2014; Teixeira et al., 2014), which, while trying to break 
through in Margolis's (1997) concept of Organizational Dignity, is based on the Habermas' communicative perspective, to consider the construction of an organizational action guided by trust and reciprocity, where communicative action is a prerequisite for the understanding of a worthy organization (Teixeira, 2008).

However, one of the most significant gaps within this field is that researches have not taken into consideration that our world is globalized, with intense movement of capital, technology, goods, workers, and employees between organizations, as well migration between countries of citizens of different countries. In other words, the concept of dignity within organizations would have to include, besides respect for different types of knowledge (technical knowledge, know-how, different cultural knowledge etc.), the idea of interculturalism.

This theoretical essay has the purpose of considering, following the thought of Boaventura de Sousa Santos, a possible conceptual proposition concerning dignity in organizations. Consequently, and consistent with an emancipatory perspective based on the founding idea of an ecology of knowledges (Santos, 2010b) and interculturalism (Santos \& Meneses, 2010), we aim to propose a concept of dignity in general and, specifically, dignity in organizations, that would transcend the sociopolitical approach to dignity.

With this critical view of such phenomenon, we seek to generate a unique conceptual contribution to the field of organizational studies. It is believed that the theoretical approach to dignity we present brings new perspectives to reflections on the behavior of individuals and interactions in groups within organizations.

Therefore, following this introduction, the article was organized in four parts. First, we present an approach to the concept of dignity. We then reflect on a possible perspective beyond a sociopolitical concept of dignity. In the third part, we ponder on dignity within organizations. Finally, some concluding considerations are provided, without any intention of ending the debate.

\section{AN APPROACH TO THE CONCEPT OF DIGNITY}

In ancient Greece, dignity was not considered a full human characteristic, nor even an absolute or sacred value, and would rather be perceived as something given only to certain groups and individuals, depending on the social status they occupied, since dignity was an attribute only for free men, and slaves were, consequently, excluded (Rabenhorst, 2001; Riley, 2010). 
The Judeo-Christian perspective was fundamental to the process of disseminating the concept of dignity as inherent to man, regardless of any conditions, that is, as something intrinsic to the human being (Gosdal, 2007); therefore, within Western world, this tradition has influenced the concept of man as inherently good, as he was regarded as the image of God (Riley, 2010). Thus, dignity could be considered a consequence of human nature or an intrinsic value to human beings, which would cause an essentialist view on human dignity. As such, dignity, while intrinsic to man, would be considered a "completely internal characteristic", but deriving from an external source, in this case, God (Koehn \& Leung, 2008).

Also, according to the Judeo-Christian tradition, it would be possible to recognize a relational characteristic in dignity, even if, ultimately, the same would reside within the individual (Koehn \& Leung, 2008). Thus, one could say that dignity was not likely to be lost, since it was intrinsic to every human being, but, on the other hand, it could easily be violated.

Thomas Aquinas, a thinker in Christian doctrine, influenced by the vision of dignity coming from God and by the rationality of the human being, affirmed the universality of human dignity (Nicolas, 2003), where man is composed of body and soul (a rational animal), and this rationality would turn that human being into a person, with a dignity of their own, simply because of their condition of being human (Aquinas, 2008). As such, dignity would derive from the image and likeness of God, which does not necessarily mean a break with the Divine, since, ultimately, the nature of Divine dignity would exceed any other dignity, so that the concept of "person" would still belong to God (Aquinas, 2011).

In the sphere of Christianity, dignity would be understood as inherent to the human being and an equal attribute of all, since human beings are created free and equal before God (Gosdal, 2007). However, since Aquinas $(2008 ; 2011)$, it has been recognized that it makes no sense to fully consider the view(s) of dignity, oriented by Christian assumptions, as inherent to the human being deriving from religious elements because of the belief in a revelation. In Aquinas' point of view, there is, explicitly, a role of free will exercised rationally.

While recognizing that Christianity became dominant in the Middle Ages, human dignity, in this historical period, would also be associated with social groups, as a result of the individual's social status. In other words, dignity could be conceived as a distinction (Gosdal, 2007).

The Renaissance brought a new challenge to the understanding of dignity, because it would integrate a positive view on man, an eminently rational being, with the view of the existence of an omnipotent God rooted in the 
Middle Ages. Man, as a being created by God and endowed with rationality, which was given by the Creator, has their own dignity by being able to make personal moral choices. Thus, this dignity would not only be inherent in the human being, but would also originate in the product of their actions (Baker, 1961; Riley, 2010). During this period, Giovanni Pico della Mirandola, while reasoning on the dignity of man, considered that it would be linked to the freedom of the human being granted by God, who wished man would understand the meaning of God's work (Mirandola, 1988).

Although these contributions of views on dignity have promoted a continuous process of philosophical and - dare we say - spiritual reflection for many authors, Immanuel Kant was considered one of the proeminent philosophers for the development of the modern concept of dignity (Abbagnano, 1998; Riley, 2010).

As per Kant, the essentiality of dignity relies in its humanity, as an intrinsic value of the human being (Abbagnano, 1998), which does not lead to a direct relationship with a religious perspective, given the fact that dignity would be founded on the very moral law of the human being. For Kant, an action would only have true moral value, if it was performed by duty, due to a pure respect for the moral law, or even due to humanity itself. In his "Groundwork of the Metaphysic of Morals," the German philosopher assigns an enlightenment influence to his conception of dignity that, moreover, would bring along the dimension of moral value that emanates from humanity itself (Kant, 2005).

The Kantian influence on the idea of dignity has shaped the modern understanding of the word, giving basis for some legal approaches in the Western world (Bostrom, 2007; Carozza, 2008; McCrudden, 2008; Riley, 2010), being even crucial to the understanding of human rights under a universalist perspective (Sarlet, 2008). The Universal Declaration of Human Rights of 1948, for example, welcomed "human dignity as a value to illuminate the universe of rights" (Piovesan, 2005, p. 46).

Unlike the concepts of dignity, as a distinction to or even as inherent in the human being, there is also the concept that presents dignity as being built by interactions among people, so that, while encounters take place, it can be promoted or violated (Jacobson, 2007).

In the approach named as the sociopolitical conception of dignity, this would not be considered as inherent to human beings, but rather as something to be preserved and guaranteed by the universal right through the clash of social and political forces within the State (Medeiros, 2013). In this line of thought, we should point out the concept of human dignity held by civil society and the democratic process, based on communicative action and 
popular participation (Habermas, 2010); the view that it is through words and actions that we integrate ourselves into the human world, and this integration can be seen as confirmation of the single and original fact of our physical appearance, or as a second birth (Arendt, 2000).

Regarding, specifically, the issue of plurality as a basic condition for action and speech, there is the double aspect of equality and difference, which takes us to the ideas of politics, the clash of ideas and interests at a society level, and the need for democratic coexistence (Arendt, 2000). However, especially regarding the question of difference, while acknowledging the blunt contribution of Arendt to the process of emancipatory social transformation, there is no indication that Arendt has moved herself away from a Eurocentric approach, considering that her reflection does not include an intercultural perspective from the South epistemologies.

\section{BEYOND A SOCIOPOLITICAL CONCEPT OF DIGNITY}

In Foucault's analytics of power, power relations do not constitute a structure above society, but rather something that is rooted into the social relations (Foucault, 1995). In large part, the concerns of Foucalt paused on the possibility of counter-powers (Foucault, 1988), so that "refusing to be ruled by others" would be designated as a critical attitude (Foucault, 1990). Thus, when considering the defense of the concept of "a decisive will of not being governed" (Fonseca, 2002, p. 267), it would be possible to think that, "refusing to be governed is a way to express a discourse of dignity, or rather that the refusal of being governed is underlying a dignity discourse" (Louback, 2012, p. 11).

To Agamben (2007, p. 12), "death prevented Foucault from developing all the implications of the concept of biopolitics." In another direction, but complementary to the criticism addressed to Foucault, Agamben focused his attention on Hannah Arendt, specifically on the work "The Human Condition," as he considered strange the absence of a connection to the biopolitics perspective: according to his view, it was totally absent in the "penetrating analysis that she had previously devoted to totalitarian power" (Agamben, 2007, p. 12). The alleged complementarity with Foucault would happen, in this case, because Foucault had never "turned his research to areas that were by nature of modern biopolitics: the concentration camp and the structure of the great totalitarian states of the twentieth century" (Agamben, 2007, p. [indicar página da citação direta]). To Agamben (2007), the concentration camp would, by nature, be the place of bio(thanato)politics. 
From the gaps identified by Agamben, his major concern would be directed to this "hidden point of intersection between the legal-institutional model and the biopolitical model of power" (Agamben, 2007, p. 14). It was in this direction that the figure of homo sacer was introduced into the discussion, the one who could not be sacrificed but could be killed; the one who, due to the exercise of thanatopolitics, would have his life reduced to a mere biological existence. The homo sacer is "an obscure figure of archaic Roman law, in which human life is included in the order only under the form of its exclusion" (Agamben, 2007, p. 16). Given this view, it should be asked: where would this dignity be or what would it be from this perspective?

Thus, while relating dignity with the bio(thanato)politics perspective, it was considered that we should leave from the same point Agamben left, which was the Aristotelian political theory, where man, like any other living creature, would be zoe, a mere biological existence; however, "the link between a bare life and politics is the same as the metaphysical definition of man as a living being who uses the language" (Agamben, 2007, p. 15). It would be through the ability of using language that the human being would develop their political existence, that is, would become able to overcome the condition of zoe to become politikòn zôon and so, a political bios.

In the view of Agamben (2007, p. 16), "politicization' in bare life is the metaphysical task by nature, in which the humankind of the living man is decided [...]," so that, for Aristotle, "man was a living animal, and moreover, capable of political existence" (Agamben, 2007, p. 15). Joining the pólis, according to the Aristotelian view, would occur because of "good living, as the ultimate purpose of the political existence of man" (Agamben, 2007, p. 15).

By relating the passage from natural life to a qualified life, i.e., the passage from zoe to political bios, it appears that the qualifying element of human experience, that is, the very practice of our political existence, would be the core of human dignity or the ultimate expression of Man's humanity.

As per Azevedo (2013), Agamben's search, in clarifying the idea of the death camp as a paradigm of sovereign power in the contemporary world, made him realize the production of an indiscernibility zone between man and non-man. That is, we would come to a "point where, although keeping the appearance of man, man ceases to be human" (Agamben, 2008, p. 62). So, we may infer that dignity has a direct relation to the human condition itself, the condition of man as a human being, or even the condition of never stopping to be human; of never being deprived of the form of humanity (Agamben, 2008).

In a certain sense, one could perceive that there would be no emancipatory exit for the subject in Agamben (2008), which, in some way, would also 
be true to Foucault $(2009 ; 1988)$. Such observation is supported by the disagreement of Santos (2010a) with Foucault's approach to power, leading to an oppression concept from which it would not be possible to think about emancipation.

Conversely, while trying to take dignity from a de-colonial perspective, we could glimpse some opening against control mechanisms developed at an industrial scale by modernity, understood as a self-narration of actors and institutions which, from the Renaissance movement, have conceived themselves as the center of the world (Mignolo, 2002; 2006; 2013). Thus, there should be place for reflection and report on the colonization of "human rights" - we could also say of dignity - by a modern rationality, which would cause the decolonization of the concepts of humanity and human, and could begin by abandoning the idea of universal humanity imposed by the white, heterosexual, Christian Western, deconstructing it to then be rebuilt it from the human diversity of the world and knowledge (Mignolo, 2013). One way to achieve this could be the decolonization of knowledge and culture, because "there is no obligation to keep Western principles and concepts untouched" (Mignolo, 2013).

Mignolo is essentially saying that it is necessary to respect the differences in concepts of human rights around the world, instead of taking the modern and Western view as universal, in the same way as we must respect the "difference of alternative concepts of human dignity" (Santos, Meneses, \& Nunes, 2005, p. 25).

Thus, from the idea of an ecology of knowledges ${ }^{1}$, Medeiros (2013) tried to elicit understanding of a single meaning of emancipation and dignity, somehow opposing a universalizing emancipatory perspective. In this direction, human dignity, or the concept of human rights, would be considered from the perspective of different cultures in their different environments, in order to demonstrate the need to achieve sociopolitical changes in different structural spaces.

However, even acknowledging the importance that Medeiros (2013) gives to the issue of difference recognition in his concept of dignity, we keep the impression that the intercultural perspective ${ }^{2}$ is not at the heart of her analysis.

Ecology of knowledges can be understood as a new form of relationship between scientific knowledge and other forms of knowledge, based on the possibility of diversity (see Santos, 2010b).

2 Interculturalism should lay on mutual recognition and availability for mutual enrichment between different cultures that share a given cultural space, a relationship based on an ecology of knowledges (see Santos \& Meneses, 2010). 
By merging the ideas of dignity and emancipation in a single meaning, it is essential to remark on what is meant by emancipation, or even of which emancipation we are discussing, having in mind it is a central category within the critical theory of modernity itself. Therefore, a reflective effort becomes necessary on some components of critical theory and the postmodern movement.

Critical theory, while based in central praxis and emancipation ideas, is positioned within the scope of a sociology for change (Morgan, 2007). In fact, critical theory as a breakthrough of the enlightenment project, is intended to be prescriptive, and more propitiating of means to face reality as a guiding source for the emancipation of humanity, having the current system of domination as a counterpoint (Nobre, 2004).

So, what is sought in critical theory is the introduction of substantive reasoning in place of instrumental reasoning, recognizing that the latter is omnipresent in Western thought, as well as responsible for the end of reasoning itself (Adorno \& Horkheimer, 2006). Enlightenment would be the only way for human beings to grow from their nonage, this being understood as "the inability to make use of one's reasoning without orientation from others. It appears as the inability to save oneself" (Adorno \& Horkheimer, 2006, p. 72). In an emancipatory perspective, it is considered that, as a subject, the human being must be able to transform himself (Adorno \& Horkheimer, 2006). As per Medeiros (2013), the alienation process would frustrate the subject's emancipation possibilities, as well as the possibility of that subject being recognized as a worthy being.

However, as a severe criticism of a universalizing prescription coming "from above", it is possible to consider that such a view would lead to a totalitarian or bureaucratic subjection of social actors to the absolute power of a political elite, which would claim legitimacy from a presumed knowledge of the laws of history (Touraine, 1994). Thus, paradoxically, in the same sense of a "decay/decline of modernity" - of its assumptions and meta-theoretical foundations - according to the post-modern critics, or of a "disillusionment with modernity" in the case of critical theorists (Alvesson \& Deetz, 1998), some would consider that "the liberating force of modernity weakens with triumphs" (Touraine, 1994, p. 99).

To Vieira and Caldas (2007), critics and postmodernists would only have in common their opposition to the mainstream that preceded them, the logical positivism. While reflecting on the significant differences and similarities between critical theory and postmodernism, in endeavoring to open tensions and provide for temporary units, Alvesson and Deetz (1998) put the two meta-theories of representational practices within the field of dissent, also 
perceived as the sociology field for change/conflict. This identification brought reactions from critical theorists, as the "criticism to fundamental and utopian ideals has been perceived by some as representing clearly apolitical positions, socially irrelevant, or even neoconservative" (Alvesson \& Deetz, 1998, p. 230). In other words, for the critical theorists, postmodernists would have put aside the struggle for the emancipation of humanity.

However, according to Chia (2003), the postmodern movement is designed to give voice and legitimacy to forms of tacit and non-represented knowledge that modern epistemology is hiding in the process of knowledge creation, and such statement is considered the real purpose and value of postmodern criticism of the assumptions and foundations of modernity. In this sense, modern rationality would minimize the flow of phenomena and the less visible lived experience, interpreting it as a form of manipulation and control. The social world would be, according to modern design, the result of the inexorable progress of immutable laws and universal principles (Chia, 2003).

In such view, a fundamental difference between the critical theorists and postmodernists, dare we say, would be the attempt of the former to "rescue" the original assumptions of modernity that had been distorted; on their side, postmodernists would emphasize "the critical extremism of postmodernism, seeing it as part of a broader critical tradition that challenges status quo and supports silenced or marginalized voices" (Alvesson \& Deetz, 1998, p. 229).

Returning to the central question of emancipation, it should be pointed out, by way of clarification, that the concept of social emancipation in Santos differs from the concept defended by critical theory, since the latter is based on a universalizing narrative goal. This perspective is not allowed in the view of critical post-modernity, since its purpose is the transformation of unequal power relations into relations of shared authority (Santos, $2010 b$ ), from the proposition of a global re-politicization of social practice (Santos, 2010a; 2010b). Politicizing should be understood as "identifying power relations and imagining practical ways to change them into shared authority relations" (Santos, 2010a, p. 271).

In fact, Santos tries to propose a new theory of emancipation, which notion has a strong democratic component that could also be named as a new democratic theory (Santos, 2010b). In this concept, we should perceive a process and not a purpose, in which the expansion and deepening of democratic struggles in various fields of social practice would be the very meaning of the processuality of emancipatory struggles (Santos, 2010b).

Moreover, "such a conception of emancipation involves the creation of a new political common sense [...]. The principle of community is revalued, 
and with it, the idea of equality without sameness, the idea of autonomy and the idea of solidarity" (Santos, 2010b, p. 277-278), so that it can be understood that the process of social transformation should be based on the principle of equality and recognition of difference (Santos, 2010b).

We should consider that the concept of postmodernity in Santos's thought doesn't refuse modernity, at least regarding the question of emancipation. However, the idea of postmodernity as a radical criticism of Western modernity should provide a new critical theory, so that the idea of social transformation don't become into a new form of social oppression (Santos, 2010b). As such, recognition of that difference would be the key differentiating element of the theoretical contribution to a new political emancipatory culture, that is, the proposition of a critical postmodernity (Santos, 2010b).

It should be also added that, in his intellectual journey, Santos will introduce the reinvention of social emancipation, the victims' experience, or learning from the South ${ }^{3}$, which would mean transcending the critical theory produced by the North (Santos, 2010b). We can also see, therefore, the search for an externality to Western modernity, as the violence of colonialism was never included in the Western's self-representation (Dussel, 2000; Mignolo, 2002; Santos, 2010b).

As an emancipatory perspective, but not within the spectrum of critical theory, we could point out Santos's criticism of the dominant paradigm, which, while recognizing and defending the importance and effectiveness of human rights and human dignity, does so from an understanding that such topics should be addressed according to a perspective that considers the different cultures in their different spaces, a point of view shared by Mignolo (2013). An understanding of the world as a counterhegemonic concept, based on an ecology of knowledge, was the underlying concept to this view (Santos, 2007a; 2010b; 2011).

According to Nunes (2006), Santos believes in social transformation as a means to build a new reality, and pursues such intent from a non-hierarchic recognition of different knowledges and the rights of communities. The base idea is that cultures include different views about human dignity, given that there is a cultural incompleteness phenomenon, which raises the need to overcome the debate on universalism and, more precisely, the Western universalist pretension (Mignolo, 2013; Santos \& Nunes, 2010).

As per Medeiros (2013), Santos would conceive emancipation and human dignity from the perspective of ecologies and the recognition of kno-

By Global South, we may refer to "developing," "poor," "peripheral" countries, or the "Third World". South is used as a metaphor to represent the human suffering caused by capitalism. 
wledges and rights; dignity, as the foundation of the right to be conquered, should not be due only by the struggle for equality but, above all, by the recognition of differences, which would raise the need to consider human rights in a multicultural perspective.

At this point, however, it is acceptable that there is a perspective beyond a multicultural concept, which would be that based on the idea of interculturalism. Incidentally, Medeiros (2013, p. 28) admits that Santos already advocated "the need to establish an intercultural dialogue on human dignity and that, from it, a mixed understanding of human rights has resulted."

Thus, in view of this discussion, we would ask if there is an intercultural approach to dignity? Or even whether there is an approach that transcends a multiculturalist view? We would say that the answer is yes; moreover, in this direction, it seems accurate to say that what is meant by dignity is the same as an emancipation process built from respect for the principles of equality and difference, as well as from the different knowledges and rights designed in different structural spaces, by means of mutual recognition and availability for mutual enrichment between different cultures sharing a given cultural space, based on relations embodied in a knowledge ecology.

\section{DIGNITY IN ORGANIZATIONS: FOR A LOOK BEYOND MODERNITY}

Following Santos (2009), an organization can be understood as a productive space in which social and knowledge practices occur, while the organization may be focused on production, technology, vocational training, and corporate culture. According to Medeiros (2013, p. 40), Santos "presents alternatives to explain how it is possible to think of a new reality in organizations."

Thus, even following a sociological perspective, what would be the relevance of taking the organization as a privileged object of analysis for social reality? For Manzini-Covre (2003), the apprehension of objective/ subjective facts within organizations, can be a way to understand certain aspects of social reality, because "it is within these living organisms that much of the social and individual life takes place" (Manzini-Covre, 2003, p. 78-79).

In our view, it is also achieving a utopian-realist attitude to contemplate a new reality for organizations from the pursuit of respect for different 
knowledges non-hierarchically defined, i.e., to exercise reflection on the dignity in organizations, from a dignity perspective, according to the thought of Santos.

In this sense, considering we live in a globalized world, with intense movement of capital, technology, goods, workers, and employees between organizations, as well as migration between countries of citizens of different countries, the concept of dignity in organizations would need to include, besides respect for different knowledges (technical knowledge, know-how, different cultural knowledges etc.), the idea of interculturalism.

Within this perspective, it is considered that there would be dignity in organizations wherever relations inside them were embodied in three pillars: the change of unequal power relations into relations of shared authority, which would integrate respect for the principles of equality and difference; the ecology of knowledges (of different knowledges); and mutual recognition and availability for mutual enrichment between different cultures that share a given cultural space.

This conception of dignity in organizations is part of an episteme that serves not only prudent knowledge but, above all, a decent life (Santos, 2011; 2006), breaking with the hegemonic monoculture of management from the North, assumed to be the discourse of truth within organizations and in business administration programs available for training of managers (Santiago \& Machado, 2015).

It can be accepted that the concept of dignity in organizations beyond modernity, based on an emancipatory perspective, necessarily involves the review of power and decision-making structures within organizations, in which the participation of different stakeholders is guaranteed, having in mind both the balance of interests (Freeman, 1984) and fair (Wright, 2011) and legitimate relationships, considering legitimacy as "a perception or widespread assumption that the actions of an entity are desirable, adequate and appropriate within some socially constructed systems of norms, values, beliefs and definitions, justifying its right to exist" (Barakat, Freitas, Boaventura, \& MacLennan, 2016).

The ecology of knowledges implies the recognition and sharing of different knowledges and experiences, breaking with the monoculture of scientific knowledge (Santos, 2010b). According to Santos (2010b; 2011), the monoculture of scientific knowledge renders illegitimate any other knowledge not based on the principles of scientific work. In the field of knowledge and management practice, it has been scientific knowledge, particularly that of American origin and some traditional European patterns, that justifies management actions (Santiago \& Machado, 2015), as well as promoting 
the corporatization of society (Rodrigues, 2011). Within organizations, the ecology of knowledges requires recognition and legitimization of different experiences and tacit knowledge, regardless the position occupied by the subjects within the organizational structure.

It is associated with the ecology of knowledges the indispensable mutual recognition and availability for mutual enrichment among the subjects that are part of the organization, whether within the same cultural space, with a texture of its own, or in diverse cultural spaces, each one characterized by a uniqueness that may be translated, as Santos (2010b) points out, into an intercultural experience.

The experience of shared authority, the recognition of different knowledges, and the mutual recognition associated with availability for mutual enrichment between different cultures that share a given cultural space, are all embodied in basic assumptions of dignity in organizations, building emancipation for the individuals that form the organization, recognizing them as agent individuals with diverse knowledges.

Dignity in organizations, in an emancipatory concept beyond modernity, also demands rethinking of management assumptions and the scientific knowledge of the Northern mainstream, to recognize the knowledge that comes from self-management experiences and a solidarity economy, from small entrepreneurs or workers from different cultural and professional backgrounds, from different positions in the social structure, and different geographical nuances in favor of intercultural experience.

Considering that interculturality, while seen by the threads of shared authority, the ecology of knowledge, mutual recognition, it can can be said that this idea is embedded in the emancipatory organizational dignity.

\section{FINAL CONSIDERATIONS}

In this paper, our intention was to reflect, following the line of thought of Boaventura de Sousa Santos, on a conceptual proposition about the phenomenon of dignity within organizations, which would transcend the sociopolitical approach to dignity. We could discern a theoretical gap for this topic, as the phenomena in focus were not being considered from an emancipatory perspective.

As such, we tried to argue in favor of the defined conceptual propositions, in that sense, the limitations of current or dominant views on those phenomena were the starting point for our emancipatory perspective. In accordance with the thinking of Santos, it was understood to be possible to 
propose "alternative" conceptual definitions, both in relation to dignity itself and to the dignity in organizations.

It is believed that the theoretical approach to dignity we present brings new perspectives to reflections on the behavior of individuals and interactions in groups within organizations. Furthermore, it is understood that the topic of dignity in organizations allows for interconnection between the management with people to human and social management at an organizational level, including, and above all, from the perspective of labor relations.

This article's purpose was to contribute to the field of organizational studies from the emancipatory and decolonial perspective of Santos, and to elucidate the field of human and social management in organizations, through discussion of dignity at an organizational level from the perspective of social emancipation.

As a theoretical contribution, we sought to introduce a new perspective on the dignity phenomenon; thus, we tried to break through, in this field of studies, with a view that understands dignity and emancipation as a single concept, in which the new element would be interculturalism. In fact, this was a step forward in the concept of dignity and emancipation in a postmodern approach, in which the recognition of knowledges appears as a central theoretical element in our language.

It is also believed that a view on dignity that emphasizes recognition of equality and difference, based on an ecology of knowledges, should have a place in today's world, especially in circumstances of intense globalization and pronounced tension.

In this sense, while discussing interculturalism, we had to accept that the idea of recognition of knowledges became central in our theoretical effort, as the basis of the proposed dignity concept in itself. Dignity, perceived as recognition of knowledges and rights, represented by the existence of an ecology of knowledges, has a relational nature, which consequently raises the need to consider it within a network of complex relationships.

As a suggestion for future studies, we consider it would be relevant and timely to conduct an depth reflection, with an emancipatory perspective, on the use of the terms "multiculturalism" and "interculturalism" in the context of organizational studies, as those terms may direct us to different theoretical and methodological problems.

Regarding the limitations of this paper, there is a need to reflect on the methodological possibilities of the concept of emancipatory dignity that can be understood beyond modernity. 


\section{DIGNIDADE NO ÂMBITO DAS ORGANIZAÇõES: UM OLHAR PARA ALÉM DO MODERNO}

\section{RESUMO}

Objetivo: O propósito deste artigo foi o de refletir, à luz da perspectiva da pós-modernidade crítica, sobre uma possível proposição conceitual acerca da dignidade nas organizações.

Originalidade/lacuna/relevância/implicações: No campo dos estudos organizacionais, não se tem considerado a dignidade nas organizações a partir da constatação de um mundo de intensa movimentação de capital, tecnologias, mercadorias, trabalhadores, empregados entre as organizações, além da migração entre cidadãos de diferentes países. Defende-se que a concepção do fenômeno ora estudado precisaria contemplar o respeito aos diferentes saberes, além da ideia de interculturalidade.

Principais aspectos metodológicos: Como há poucos trabalhos sobre tal temática, o presente trabalho configura-se como um ensaio teórico.

Síntese dos principais resultados: A partir de uma aproximação ao conceito de dignidade, procurou-se delinear uma abordagem conceitual que visou transpor a sua concepção sociopolítica e, então, a partir disso, se propor um olhar para além do moderno à dignidade nas organizações. As ideias sobre ecologia de saberes, relações de autoridade partilhada, respeito aos princípios da igualdade e da diferença, além do reconhecimento recíproco e a disponibilidade para o enriquecimento mútuo mostraram-se como elementos qualificadores na definição de nossas proposições conceituais.

Principais considerações/conclusões: Como contribuição teórica, buscou-se trazer um novo olhar sobre o fenômeno da dignidade, de modo que se tentou avançar no campo de estudos a partir de uma visão que entende a dignidade e a emancipação como um único conceito, cujo novo elemento seria o da interculturalidade.

\section{PALAVRAS-CHAVE}

Dignidade nas organizações. Emancipação. Interculturalismo. Modernidade. Pós-modernidade. 


\section{DIGNIDAD EN EL CONTEXTO DE LAS ORGANIZACIONES: UNA MIRADA MÁS ALLÁ LA MODERNIDAD}

\section{RESUMEN}

Propósito: Este artículo tiene por objectivo reflexionar, a la luz de la perspectiva de la posmodernidad crítica, sobre una posible propuesta conceptual acerca de la dignidad en las organizaciones.

Originalidad/laguna/relevancia/implicaciones: En el campo de los estudios organizacionales, no ha tenido en cuenta la dignidad de las organizaciones desde el punto de vista de la realización de un mundo de intensa circulación de capitales, la tecnología, los bienes, los trabajadores, los empleados de las organizaciones, así como la migración entre ciudadanos de diferentes países. Se argumenta, por lo tanto, que el diseño del fenómeno estudiado ahora tiene que mirar más profundamente en el respeto de los diferentes conocimientos, la idea de la interculturalidad. Principales aspectos metodológicos: Existen pocos artículos escritos sobre este tema, por lo que nuestro trabajo se trata de un ensayo teórico. Síntesis de los principales resultados: Tomando el concepto de dignidad como punto de partida, hemos tratado de esbozar un enfoque conceptual destinado a adaptar su perspectiva sociopolítica, con el objetivo de proponer un vistazo a la dignidad de las organizaciones más allá de la modernidad. La ecología de saberes, las relaciones de autoridad compartida, el respeto a los principios de la igualdad y la diferencia, más allá del reconocimiento recíproco y la disponibilidad para el enriquecimiento mutuo son los elementos que precisan para definir nuestras proposiciones conceptuales.

Principales consideraciones/conclusiones: Se cree que el enfoque teórico que aquí se propone, hemos tratado de aportar una nueva mirada sobre el fenómeno dela dignidad, de modo que llegamos a un avance en el campo de estudio a partir de una visión que entiende la dignidad y la emancipación como un solo concepto, en el que el nuevo elemento será la interculturalidad.

\section{PALABRAS CLAVE}

La dignidad de las organizaciones. Emancipación. Interculturalidad. Modernidad. Posmodernidad. 


\section{REFERENCES}

Abbagnano, N. (1998). Dicionário de filosofia. São Paulo: Martins Fontes. Adorno, T., \& Horkheimer, M. (2006). Dialética do esclarecimento. Rio de Janeiro: Jorge Zahar.

Agamben, G. (2007). Homo sacer: o poder soberano e a vida nua I. Belo Horizonte: Editora UFMG.

Agamben, G. (2008). O que resta de Auschwitz (Homo Sacer III). São Paulo: Boitempo.

Alvesson, M., \& Deetz, S. (1998). Teoria crítica e abordagens pós-modernas para estudos organizacionais. In S. R. Clegg, C. Hardy, \& W. R. Nord (Eds.). Handbook de estudos organizacionais. (Vol. 1, pp. 226-264). São Paulo: Atlas.

Aquinas, T. (2008). O ente e a essência [Opúsculo]. Tradução do original em Latim de Mário Santiago de Carvalho. Corvilhã: LusoSofia Press. Retrieved from www.lusofia.net/textos/aquino_tomas_de_ente_et_essentia.pdf.

Aquinas, T. (2011). Summa Theologica. [1265-1274] Complete \& Unabridged American Edition Translated by Fathers of the English Dominican Province. Kindle Edition.

Araújo, B. F. V. B. (2011). Dignidade no âmbito da relação entre empresas e comunidade. Tese de Doutorado em Administração de Empresas, Universidade Presbiteriana Mackenzie (UPM), São Paulo, SP, Brasil. Retrieved from http:// tede.mackenzie.br/jspui/handle/tede/787.

Arendt, H. (2000). A condição humana. (10th ed). Rio de Janeiro: Forense Universitária.

Auerbach, J. (1988). Organized labor: toward a new dignityin the workplace. Journal of Career Development, 15(1), 65-77.

Azevedo, E. E. B. (2013). O campo de extermínio como paradigma do poder soberano na contemporaneidade. Cadernos Benjaminianos, Número especial, Belo Horizonte, 77-88.

Baker, H. (1961). The image of man. New York: Harper \& Brothers.

Barakat, S. R., Freitas, L. P., Boaventura, J. M. G., \& Maclennan, M. L. F. (2016). Legitimidade: uma anállise da evolução do conceito na teoria dos stakeholders. Revista de Ciências da Administração, 18(44), 66-80.

Barbee, G. (2001). Downsizing with dignity: easing the pain of employee layoffs. Business and Society Review, Pages, 31-34.

Bayer, R. (2000). Termination with dignity. Business Horizons, 43(5), 4-10. 
Beitner, E. I. (1984). Justice and dignity: a new approach to discipline. Labor Law Journal, 35(8), 500-505.

Bostrom, N. (2007). Dignity and enhancement. Oxford Future of Humanity Institute. Faculty of Philosophy \& James Martin $21^{\text {st }}$ Century School. Oxford University.

Brodie, D. (2004). Protecting dignity in the workplace: the vitality of mutual trust and confidence. Industrial Law Journal, 33(4), 349-354.

Buchanan, R. (2001). Human dignity and human rights: thoughts on the principles of human centered design. Design Issues, 17(3), 35-39.

Campos, H. R., \& Alverga, A. R. (2001). Trabalho infantil e ideologia: contribuição ao estudo da crença indiscriminada na dignidade do trabalho. Estudos de Psicologia, 6(2), 221-233.

Carozza, P. G. (2008). Human dignity and judicial interpretation of human rights: a reply. The European Journal of International Law, 19(5), 931-944.

Chia, R. (2003) Organization theory as a postmodern science. In H. Tsoukas \& C. Knudsen (Eds.). The Oxford Handbook of Organization Theory. (pp. 113140). Oxford: Oxford University Press.

Chiappetta-Swanson, C. (2005). Dignity and dirty work: nurses' experiences in managing genetic termination for fetal anomaly. Qualitative Sociology, 28(1), 93-116.

Crowley, M. (2013). Gender, the labor process and dignity at work. Social Forces, 91 (4), 1209-1238.

Dussel, E. (2000). Ética de la liberación en la edad de la globalización y de la exclusión. Madrid: Trotta.

Ferreira, A. B. H. (1999). Novo Aurélio XXI: o dicionário da Língua Portuguesa (3rd ed). Rio de Janeiro.

Fonseca, M. A. (2002). Michel Foucault e o direito. São Paulo: Max Limonad.

Foucault, M. (1988). História da sexualidade I: a vontade de saber. Rio de Janeiro: Edições Graal.

Foucault, M. (1990). Qu'est-ce que la critique? Critique et Aufklarung. Bulletin dela Société Française de Philosophie, 82(2), 35-63.

Foucault, M. (1995). O sujeito e o poder. In H. Dreyfus \& P. Rabinow (Eds.). Michel Foucault, uma trajetória filosófica: para além do estruturalismo e da hermenêutica. Rio de Janeiro: Forense Universitária.

Foucault, M. (2009). Vigiar e punir: história da violência nas prisões. Rio de Janeiro: Vozes. 
Freeman, R. E. (1984). Strategic Management: a stakeholder approach. Cambridge: Cambridge University Press.

Gosdal, T. C. (2007). Dignidade do trabalhador: um conceito construído sob o paradigma do trabalho decente e da honra. São Paulo: LTr.

Greenspan, D. S. (2002). Downsizing with dignity. Employment Relations Today, 9(3), 39-48.

Greenspan, D. S. (2010). The concept of human dignity and the realistic utopia of human rights. Metaphilosophy, 41 (4), 464-480.

Heloani, R. (2004). Assédio moral: um ensaio sobre a expropriação da dignidade no trabalho. RAE - Eletrônica, 3(1), 1-8.

Hodson, R. (1996). Dignity in the workplace under participative management: alienation and freedom revisited. American Sociological Review, 61 (5), 719-738.

Hodson, R. (2001). Dignity at work. Kindle Edition.

Hodson, R., \& Roscigno, V. J. (2004). Organizational success and worker dignity: complementary or contradictory?. American Journal of Sociology, 110(3), 672-708.

Horkheimer, M. (2002). Traditional and critical theory. In M. Horkheimer (Ed.). Critical Theory: Selected Issues. New York: The Continuum Publishing. Jacobson, N. (2007). Dignity and health: a review. Social Science \& Medicine, 64(2), 292-302.

Kant, I. (2005). Fundamentação da metafísica dos costumes e outros escritos. São Paulo: Martins Claret.

Kant, I. (2012). Resposta à pergunta: que é "Esclarecimento"? (Aufklarung). In I. Kant. Immanuel Kant: textos seletos. Petrópolis, RJ: Vozes.

Koehn, D., \& Leung, A. (2008). Dignity in Western versus in Chinese culture: theoretical overview and practical illustrations. Business \& Society Review, 113(4), 477-504.

Lawless, J., \& Moss, C. (2007). Exploring the value of dignity in the work-life of nurses. Contemporary Nurse: A Journal for the Australian Nursing Profession, 24(2), 225-236.

Louback, J. C. (2012). Dignidade e relações de poder: um estudo em um call center à luz de Foucault. Tese de Doutorado em Admninistração de Empresas, Universidade Presbiteriana Mackenzie (UPM), São Paulo, SP, Brasil. Retrieved from http://tede.mackenzie.br/jspui/handle/tede/790.

Manzini-Covre, M. L. (2003). Sofrimento em organismos sociais e cidadania-em-constituição. In T. Aiello-Vaisberg \& F. Ambrosio (Orgs,). Trajetos do 
Sofrimento: rupturas e (re)criações de sentido. São Paulo: Instituto de Psicologia da Universidade de São Paulo.

Margolis, J. D. (1997). Dignity in the balance: philosophical and practical dimensions of promoting ethics in organizations. Ph.D. dissertation, Harvard University, Cambridge, United States of America.

McCrudden, C. (2008). Human dignity and judicial interpretation of human rights. The European Journal of International Law, 19(4), 655-724.

McMullen, J. (2011). Balancing the right to manage with dignity at work. Perspectives: Policy \& Practice in Higher Education, 15(1), 3-6.

Medeiros, A. L. (2013). Cartografia simbólica da dignidade dos docentes de universidades brasileiras: uma reflexão à luz de Boaventura de Sousa Santos. Tese de Doutorado em Administração de Empresas, Universidade Presbiteriana Mackenzie (UPM), São Paulo, SP, Brasil. Retrieved from http://tede.mackenzie.br/ jspui/handle/tede/806.

Mignolo, W. (2002). The geolopolitics of knowledge and the colonial difference. The South Atlantic Quarterly, 101 (1), 57-96.

Mignolo, W. (2006). Os esplendores e as misérias da "ciência": colonialidade, geopolítica do conhecimento e pluri-versalidade epistêmica. In B. S. Santos (Ed.). Conhecimento prudente para uma vida decente: um discurso sobre as ciências revisitado (2nd ed). São Paulo: Cortez.

Mignolo, W. (2013). Decolonialidade como caminho para a cooperação. Entrevista. Revista do Instituto Humanitas Unisinos - IHU On-line, 431(XIII). Retrieved from http://www.ihuonline.unisinos.br/index.php?option=com content\&view $=$ article\&id $=5253 \&$ secao $=431$.

Mirandola, G. P. D. (1998). A dignidade do homem. São Paulo: GRD.

Morgan, G. (2007). Paradigmas, metáforas e resolução de quebra-cabeças na teoria das organizações. In M. P. Caldas \& C. O. Bertero (Eds.). Teoria das organizações. (pp. 12-33). São Paulo: Atlas.

Morkhiber, C. G. (2001). Toward a measure of dignity: indicators for right-based development. Statistical Journal of the UN Economic Commission for Europe, 18(2/3), 155-162.

Nicolas, M. J. (2003). Introdução à Suma Teológica. In M. J. Nicolas. Suma Teológica (pp. 1265-1274, 2nd ed.). São Paulo: Edições Loyola.

Nobre, M. (2004). A teoria crítica. Rio de Janeiro: Zahar.

Nunes, J. A. (2006). Um discurso sobre as ciências 16 anos depois. In B. S. Santos (Ed.). Conhecimento prudente para uma vida decente: um discurso sobre as ciências revisitado. (pp. 59-84, 2nd. ed.). São Paulo: Cortez. 
Piovesan, F. (2005). Direitos humanos, o princípio da dignidade humana e a Constituição brasileira. Revista dos Tribunais (São Paulo), 833(94), 41-53.

Rabenhorst, E. R. (2001). Dignidade humana e moralidade democrática. Brasília: Brasília Jurídica.

Rayman, P., \& Reynolds, J. (2001). Beyond the bottom line: the search for dignity at work. New York: Palgrave.

Riley, S. (2010). Human dignity: comparative and conceptual debates. International Journal of Law in Context, 6(2), 117-138.

Rodrigues, R. F. (2011). A empresarialização da sociedade sob a influência da racionalidade da gestão. Sociologia: Revista da Faculdade de Letras da Universidade do Porto, 21 (I), 233-255.

Santiago, C., \& Machado, M. M. (2015). Implicações da globalização no âmbito do saber e da prática de gestão: algumas reflexões. Revista de Estudos de Gestão, Informação e Tecnologia, 2(4), 13-33.

Santos, G. O., \& Silva, L. F. F. (2009). Há dignidade no trabalho com lixo?. Revista Mal-Estar e Subjetividade, 9(2), 689-716.

Santos, B. S., Meneses, M. P., \& Nunes, J. A. (2005). Introdução: para ampliar o cânone da ciência: a diversidade epistemológica do mundo. In B. S. Santos (Ed.). Semear outras soluções: os caminhos da biodiversidade e dos conhecimentos rivais. (pp. 21-25). Rio de Janeiro: Civilização Brasileira.

Santos, B. S. (2006). Para uma sociologia das ausências e uma sociologia das emergências. In B. S. Santos (Ed.). Conhecimento prudente para uma vida decente: um discurso sobre as ciências revisitado (pp. 777-821, 2nd ed.). São Paulo: Cortez. Santos, B. S. (2007a). Para além do pensamento abissal: das linhas globais a uma ecologia de saberes. Novos Estudos - Cebrap 79(novembro), 71-94.

Santos, B. S. (2007b). Renovar a teoria crítica e reinventar a emancipação social. São Paulo: Boitempo.

Santos, B. S. (2009). Direitos humanos: o desafio da interculturalidade. Revista Direitos Humanos, 2 (junho), 10-18.

Santos, B. S. (2010a). Pela mão de Alice: o social e o político na pós-modernidade. São Paulo: Cortez.

Santos, B. S. (2010b). A gramática do tempo: para uma nova cultura política. São Paulo: Cortez.

Santos, B. S. (2011). A crítica da razão indolente: contra o desperdício da experiência. São Paulo: Cortez.

Santos, B. S., \& Meneses, M. P. (2010). Introdução. In B. S. Santos \& M. P. 
Meneses (Eds.). Epistemologias do Sul (pp. 9-20, 2nd ed.). Coimbra: Edições Almedina e CES.

Santos, B. S., \& Nunes, J. A. (2010). Introdução: para ampliar o cânone do reconhecimento, da diferença e da igualdade. In B. S. Santos (Ed.). Reconhecer para libertar: os caminhos do cosmopolitismo multicultural (pp. 25-68, 2nd ed.). Rio de Janeiro: Civilização Brasileira.

Sarlet, I. W. (2008). Dignidade da pessoa humana e os direitos fundamentais na Constituição Federal de 1988 (6th ed). Porto Alegre: Livraria do Advogado Editora.

Sayer, A. (2007). Dignity at work: broadening the agenda. Organization, 14(4), 565-58.

Shahinpoor, N., \& Matt, B. F. (2006). The power of one: dissent and organizational life. Journal of Business Ethics, 34(4), 663-683.

Stacey, C. L. (2005). Finding dignity in dirty work: the constraints and rewards of low-wage home care labour. Sociology of Health \& Illnes, 27(6), 831-854.

Teixeira, M. L. M. (2008). Dignidade organizacional: valores e relações com stakeholders. In M. L. M. Teixeira (Ed.). Valores humanos e gestão: novas perspectivas. (pp. 81-94). São Paulo: Editora Senac.

Teixeira, M. L. M., De Domenico, S. M. R., Dias, S. M. R. C., \& Mendes, L. H. L. (2014). Práticas de dignidade organizacional percebidas por trabalhadores na relação entre organização e stakeholders. Encontro da Associação Nacional de Pós-Graduação em Administração - EnANPAD, Rio de Janeiro, XXXVIII.

Teixeira, M. L. M. (2014). Facetas do constructo dignidade organizacional. Centro de Administração e Políticas Públicas - CAPP. Working paper.

Touraine, A. (1994). Crítica da modernidade. (6th ed.). Petrópolis, RJ: Vozes.

Vieira, M. M. F., \& Caldas, M. P. (2007). Teoria crítica e pós-modernismo: principais alternativas à hegemonia funcionalista. In M. P. Caldas \& C. O. Bertero (Eds.). Teoria das organizações. (pp. 291-311). São Paulo: Atlas.

Wright, T. A. (2011). And justice for all: our research participants considered as valued stakeholders. Management and Organization Review, 7(3), 495-503. 